\title{
Returns on investment in sheep and goat breeding in South Africa ${ }^{\text {is }}$
}

\author{
S.J. Schoeman ${ }^{\mathrm{a}, *}$, S.W.P. Cloete ${ }^{\mathrm{b}, \mathrm{c}}$, J.J. Olivier ${ }^{\mathrm{b}, \mathrm{d}}$ \\ a Department of Animal and Wildlife Sciences, University of Pretoria, Pretoria 0002, South Africa \\ ${ }^{\mathrm{b}}$ Department of Animal Sciences, Private Bag X1, Matieland 7599, South Africa \\ c Institute for Animal Production, Elsenburg, Private Bag X1, Elsenburg 7607, South Africa \\ d ARC: Animal Production Institute, Private Bag X5013, Stellenbosch 7599, South Africa
}

\section{A R T I C L E I N F O}

\section{Available online $\mathrm{xxxx}$}

\section{Keywords:}

Genetic resources

Performance recording

Breeding objectives

Monetary value

Small stock

\begin{abstract}
A B S T R A C T
The small stock industry in South Africa is of crucial importance as $80 \%$ of the agricultural land is unsuitable for intensive agricultural production. The contribution of 19 resource sheep flocks and goat herds towards breeding objective formulation, genetic improvement and parameter estimation was summarized. Substantial genetic gains resulting from selection for a range of economically important traits were demonstrated, lending impetus to the development and extension of the National Small Stock Improvement Scheme (NSIS). Responses in monetary values in the respective participating small stock breeds ranged from R0.098 for the Dormer to R0.818 for the S.A. Mutton Merino per small stock unit per annum for animals born in the interval from 2000 to 2006. This response is well below what was attained in the resource flocks and in the best participating flocks and herds. Even with this less than optimal change on a national basis, the impact on the sectoral economy is substantial. When related to the cost associated with the NSIS, this improvement is highly cost-effective. The impact of research and development in the small stock industry is therefore substantial, and the small stock industry is foreseen to continue playing an integral role in the national economy.
\end{abstract}

(c) 2010 Elsevier B.V. All rights reserved.

\section{Introduction}

Livestock production plays an integral role in the South African agriculture. It accounts for approximately $48 \%$ of the total value of agricultural output during the season of 2005/ 2006 (Abstract of Agricultural Statistics, 2008). Approximately $80 \%$ of the agricultural land is unsuitable for crop production, while the largest part thereof is not even suitable for either dairy or beef production. The small stock industry is consequently of crucial importance in the South African livestock environment.

Although pedigree recording and selection already started in 1904 through the establishment of the South African Studbook Association, performance recording was initiated in

\footnotetext{
is This article is part of the special issue entitled " $10^{\text {th }}$ World Conference on Animal Production (WCAP)" guest edited by Norman Casey.

* Corresponding author. 25 Coronata Street, Paradyskloof, Stellenbosch, 7600, South Africa. Fax: +27 218800174.

E-mail address: schalkc@elsenburg.com (S.W.P. Cloete).
}

1956 by the then Department of Agriculture and Technical Services. Fleece testing in South Africa has been practiced as early as $\mathbf{1 9 3 4}$, but the formal fleece testing facility at the Grootfontein College of Agriculture at Middelburg was inaugurated in 1965 (Erasmus and Hofmeyr, 1984). Since then, small stock improvement services in South Africa have undergone several changes necessitated by changes in demand, adoption of new production technologies and advanced technological (statistical) procedures. The present South African National Small Stock Improvement Scheme (NSIS), which is operated by the Animal Production Institute of the Agricultural Research Council (ARC) consists of an integrated pedigree and data recording system namely the INTERGIS. It currently provides breeding values for economically important traits to all participating members of all small stock species. These also include information in composite breeds that were developed over several decades as was dictated by needs, environmental limitations and market requirements. The most important of such breeds are the 
Dorper (meat), Dormer (meat), Afrino (dual-purpose), Dohne Merino (dual-purpose) and Boer goat (meat). The investment in the research that led to the development of these composite breeds had an incredible economic impact on the South African small stock industry as shown by their popularity, which has resulted in the flowing over of genetic material to other countries worldwide.

The objectives and other attributes of the National Small Stock Improvement Scheme are broadly the following:

- To supply breeders with objective performance information to improve the efficiency of production through genetic improvement of economically important traits and improved management practices. This also means that the perceptions of breeders have to be changed to focus on traits of monetary value to their clients (commercial producers). The most important trait to be improved is net reproduction rate under natural production environments (Olivier, 1999).

- To provide useful information for research and for the refinement of breeding objectives and improved breeding programme design.

- To provide an important instrument for human capacity development.

Initially, this scheme was guided by research done on various research flocks and herds throughout South Africa, which played a major role pertaining to the formulation of breeding objectives, the demonstration of genetic improvement, the estimation of genetic parameters and the identification and characterization of new traits of importance.

This review focuses on the values and contributions of resource flocks and herds and the eventual progress made and financial advantages in the national sheep and goat populations. Focus will mainly be placed on the input and output during the past approximately 20 years.

\section{South African small stock resource flocks and herds}

The South African small stock resource flocks and herds can be subdivided into two broad categories, namely research flocks and prestige flocks or studs maintained for demonstration. The first category mostly involved selection experiments and genotype evaluations that were carried out in a commercial environment. For the purpose of this discussion, a small number of flocks maintained for conservation purposes will be grouped with the first category. The latter category mostly involved flocks that were maintained under traditional conditions for stud breeding, but demonstrating scientific formulated breeding objectives. Economic realities resulted in the levels of management and nutrition being toned down in recent years in these flocks, with managerial inputs being more comparable to the commercial environment. Even though the main objective of some so-called stud flocks has not always included research, these flocks still yielded important scientific information. All flocks are mostly maintained by agricultural research and training institutes, that are situated throughout the sheep producing areas.

Olivier (1999) stated that the sheep selection experiments of the latter half of the 20th Century failed to grasp the imagination of the sheep farming public at large. In contrast, the public were better able to identify with the more traditionally managed flocks or studs that were maintained alongside. However, both categories contributed markedly to the improved understanding of scientific sheep breeding by the research community, and to the present South African sheep industry structures. These flocks and herds are largely self-maintaining and require no additional financial input. The important resource flocks contributing to the South African ovine knowledge base are therefore described below.

\subsection{Research flocks and herds}

The small stock resources available for genetic experimentation are listed in Table 1. The most important results from the respective flocks and herds will be discussed briefly.

\subsubsection{Klerefontein Merino flock}

Responses to selection for economically important traits in this flock, as derived from deviations from the Control flock, were disappointing in an initial study (Olivier, 1981). When it became possible to separate genetic trends from environmental trends by mixed model methodology, it was clear that genetic drift in the Control flock masked trends in live weight and clean fleece weight in the selection lines (Erasmus, 1988, 1990). It was speculated that the unintended genetic change in the Control line could be a function of random genetic drift and/or unintentional selection by the flock manager. The flock yielded data for parameter estimation for hogget live weight and wool traits (Erasmus et al., 1990; Snyman et al., 1996b), hogget traits (Snyman et al., 1998a) and reproduction (Delport, 1989; Snyman et al., 1998a; Olivier et al., 1998b). The flock was disbanded in 1983 in favour of other resource flocks that were maintained on Klerefontein.

\subsubsection{Koopmansfontein Dorper flock}

The Koopmansfonten Dorper flock was established with the view to breeding for different objectives deemed important in meat sheep breeding. Direct selection for weaning weight in ewes and rams in Group 1 resulted in the fastest direct genetic gain in this flock (Fig. 1; Neser et al., 1995). The second fastest direct genetic gain was found in the line selected according breed standards, leading Neser et al. (1995) to suggest that the breed standards must have emphasised animal size during the term of the selection experiment. The relatively poor performance of the line selected for weaning weight in ewes and for post-weaning feedlot gain in rams was unexpected. It could be that selection for post-weaning growth in the feedlot could select for other gene combinations compared to direct selection for weaning weight under pasture conditions.

Maternal genetic trends were much less pronounced than direct trends, with no clear selection line effects (Fig. 2; Neser et al., 1995). There was some evidence of an initial response in maternal breeding values in Group 2, but it was not sustained. The selection strategies applied therefore did not appear to have a marked influence on maternal breeding values for weaning weight in this flock.

\subsubsection{Tygerhoek Merino flock}

Initial results involved three lines, namely a line selected for an increased clean fleece weight with a check on fibre diameter (CFW line), a line selected for an increased wool S:P follicle ratio ( $S: P$ line), and an unselected Control line 
Table 1

Details of South African resource flocks/herds involved in research on selection and the comparison of breeds or lines.

\begin{tabular}{|c|c|c|c|c|c|c|}
\hline Flock & Breed & $\begin{array}{l}\text { Location } \\
\text { (province) }\end{array}$ & Time span & Selection objectives & Selection lines/types & Key references \\
\hline $\begin{array}{l}\text { Klerefontein } \\
\text { Merino flock }\end{array}$ & Merino & $\begin{array}{l}\text { Carnarvon } \\
\text { (Northern Cape) }\end{array}$ & $\begin{array}{l}1962- \\
1983\end{array}$ & $\begin{array}{l}\text { Increasing fleece weight and } \\
\text { improving conformation }\end{array}$ & $\begin{array}{l}\text { 1. Control line } \\
\text { 2. Fleece weight line } \\
\text { 3. Visual appraisal line }\end{array}$ & $\begin{array}{l}\text { Erasmus et al. } \\
(1990) \\
\text { Snyman et al. } \\
\text { (1996b) } \\
\text { Snyman et al. } \\
(1998 a)\end{array}$ \\
\hline $\begin{array}{l}\text { Koopmansfontein } \\
\text { flock }\end{array}$ & Dorper & $\begin{array}{l}\text { Jan Kempdorp } \\
\text { (Northern Cape) }\end{array}$ & $\begin{array}{l}1966- \\
1982\end{array}$ & $\begin{array}{l}\text { Selection for growth under different } \\
\text { scenarios }\end{array}$ & $\begin{array}{l}\text { 1. Weaning weight } \\
\text { 2. Weaning weight in ewes, post- } \\
\text { weaning feedlot gain in rams } \\
\text { 3. Subjective selection }\end{array}$ & $\begin{array}{l}\text { Neser et al. } \\
(1995)\end{array}$ \\
\hline Tygerhoek flock & Merino & $\begin{array}{l}\text { Riviersonderend } \\
\text { (Western Cape) }\end{array}$ & $\begin{array}{l}\text { 1969- } \\
\text { present }\end{array}$ & $\begin{array}{l}\text { Increasing fleece weight without } \\
\text { changing fibre diameter }\end{array}$ & $\begin{array}{l}\text { 1. Control line } \\
\text { 2. Clean fleece weight line } \\
\text { 3. S/P Line }\end{array}$ & $\begin{array}{l}\text { Heydenrych et } \\
\text { al. (1984) } \\
\text { Cloete et al. } \\
\text { (1998a) }\end{array}$ \\
\hline Upington flock & Karakul & $\begin{array}{l}\text { Upington } \\
\text { (Northern Cape) }\end{array}$ & $\begin{array}{l}\text { 1970- } \\
\text { present }\end{array}$ & Improving pelt quality & $\begin{array}{l}\text { 1. Control line } \\
\text { 2. Hair length line } \\
\text { 3. Pattern line } \\
\text { 4. Hair quality line } \\
\text { 5. Curl development line }\end{array}$ & $\begin{array}{l}\text { Greeff et al. } \\
(1993 a, b, c)\end{array}$ \\
\hline $\begin{array}{l}\text { Klerefontein } \\
\text { Namaqua flock }\end{array}$ & $\begin{array}{l}\text { Namaqua } \\
\text { Afrikaner }\end{array}$ & $\begin{array}{l}\text { Carnarvon } \\
\text { (Northern Cape) }\end{array}$ & $\begin{array}{l}\text { 1982- } \\
\text { present }\end{array}$ & $\begin{array}{l}\text { Conservation of indigenous fat- } \\
\text { tailed breed }\end{array}$ & $\begin{array}{l}\text { Live weight and reproduction traits } \\
\text { recorded }\end{array}$ & $\begin{array}{l}\text { Snyman et al. } \\
\text { (1993) }\end{array}$ \\
\hline Elsenburg flock & Merino & $\begin{array}{l}\text { Stellenbosch } \\
\text { (Western Cape) }\end{array}$ & $\begin{array}{l}\text { 1986- } \\
\text { present }\end{array}$ & $\begin{array}{l}\text { Divergent selection for reproduction } \\
\text { (number of lambs weaned) }\end{array}$ & $\begin{array}{l}\text { 1. } \mathrm{H} \text { line (selected for) } \\
\text { 2. } \mathrm{L} \text { line (selected against) }\end{array}$ & $\begin{array}{l}\text { Cloete et al. } \\
\text { (2004b) }\end{array}$ \\
\hline $\begin{array}{l}\text { Jansenville fine- } \\
\text { mohair herd }\end{array}$ & Angora & $\begin{array}{l}\text { Jansenville } \\
\text { (Eastern Cape) }\end{array}$ & $\begin{array}{l}\text { 1988- } \\
\text { present }\end{array}$ & $\begin{array}{l}\text { Selection for a reduced fibre } \\
\text { diameter }\end{array}$ & $\begin{array}{l}\text { 1. Control line } \\
\text { 2. Fine-mohair line }\end{array}$ & $\begin{array}{l}\text { Snyman } \\
(2002)\end{array}$ \\
\hline $\begin{array}{l}\text { Tygerhoek fine- } \\
\text { wool flock }\end{array}$ & Merino & $\begin{array}{l}\text { Riviersonderend } \\
\text { (Western Cape) }\end{array}$ & $\begin{array}{l}\text { 1998- } \\
\text { present }\end{array}$ & A reduced fibre diameter & $\begin{array}{l}\text { 3. Control line } \\
\text { 4. Fine-wool line }\end{array}$ & $\begin{array}{l}\text { Cloete et al. } \\
\text { (2001a) }\end{array}$ \\
\hline $\begin{array}{l}\text { Klerefontein } \\
\text { Dorper flock }\end{array}$ & Dorper & $\begin{array}{l}\text { Carnarvon } \\
\text { (Northern Cape) }\end{array}$ & $\begin{array}{l}1993- \\
2000\end{array}$ & $\begin{array}{l}\text { Comparison of lines within the } \\
\text { Dorper breed }\end{array}$ & $\begin{array}{l}\text { 1. Hairy type } \\
\text { 2. Woolly type }\end{array}$ & $\begin{array}{l}\text { Snyman and } \\
\text { Olivier (2002b) }\end{array}$ \\
\hline
\end{tabular}

(Heydenrych et al., 1984). Direct selection in the CFW line resulted in a $1.2 \%$ per annum improvement in CFW relative to the overall mean, while indirect selection resulted in a correlated response in CFW amounting to $0.4 \%$ per annum

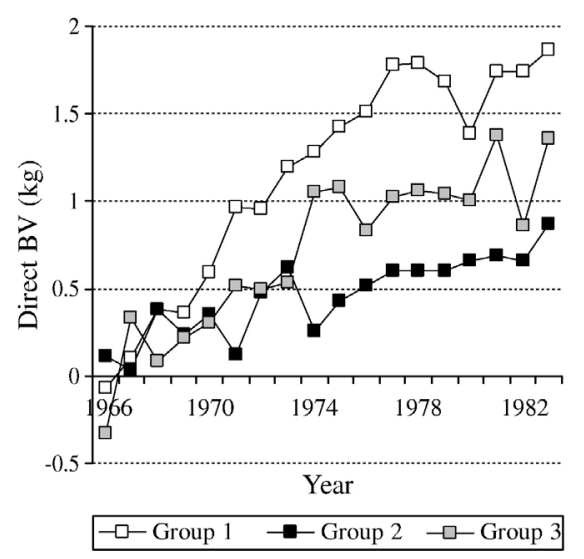

Fig. 1. Direct predicted breeding values (BVs) for weaning weight in Dorper lines selected for weaning weight (Group 1), for weaning weight in females and for post-weaning feedlot gain in males (Group 2) and for Dorper breed standards (Group 3).

The figure was derived from results presented by Neser et al. (1995). in the S:P line. Both ways of selection did not result in marked unwanted increases in fibre diameter. The S:P line was discontinued in 1982 and only the CFW and Control lines were retained.

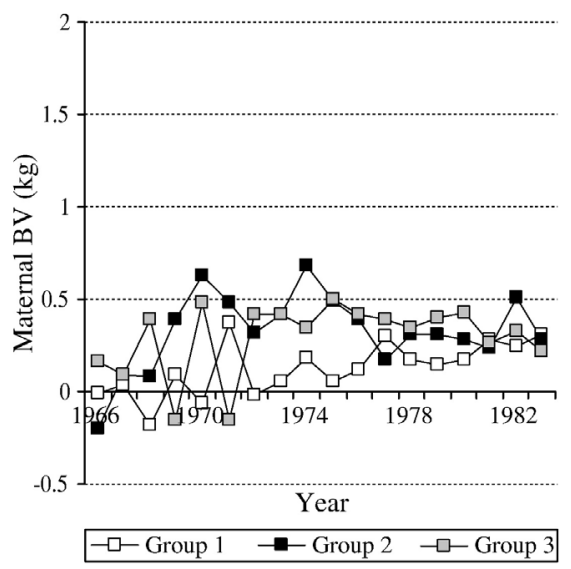

Fig. 2. Maternal predicted breeding values (BVs) for weaning weight in Dorper lines selected for weaning weight (Group 1), for weaning weight in females and for post-weaning feedlot gain in males (Group 2) and for Dorper breed standards (Group 3).

The figure was derived from results presented by Neser et al. (1995). 
Direct response to selection for clean fleece weight in the CFW line was reported to be $1.1 \%$ per annum up to 1990 expressed relative to the overall mean (Cloete et al., 1992), and $0.9 \%$ per annum up to 1996 (Cloete et al., 1998a). The Control line showed some genetic drift, in particular for live weight (Cloete et al., 1992, 1998a). This trend was related to unintended selection for size in the Control group rams, where low live weight rams performed poorly under handmating conditions (Cloete et al., 1992). Low live weight ewes were also shown to be less likely to contribute progeny for replacements to the breeding flock, because of a greater likelihood of remaining barren.

The flock also contributed data to a study investigating the heritability of total weight of lamb weaned per joining (TWW) as a reproductive trait (Snyman et al., 1998a). Positive genetic correlations of TWW were found with live weight, while correlations with fleece weight and fibre diameter were positive, but not significant.

\subsubsection{Upington Karakul flock}

Heritability estimates of pelt traits in this flock were 0.301 for hair quality and 0.344 for pattern, when adjusted for birth weight (Greeff et al., 1993a). Corresponding estimates of 0.305 and 0.336 were, respectively, computed without adjustment for birth weight. Estimates of $h^{2}$ ranged from medium to high for components of hair quality. The highest $h^{2}$ estimates were derived for curl type $(>0.40)$. No antagonistic genetic correlations were found between hair quality and pattern.

When expressed relative to the respective overall means for the traits, direct genetic trends amounted to $2.5 \%$ for pattern, $1.3 \%$ for hair quality, $2.96 \%$ for hair length and $7.1 \%$ for curl development (Greeff et al., 1993b). The Control line did not remain stable, as small positive changes were found for pattern and hair quality. In contrast, curl development and hair length showed slight unfavourable genetic trends in the Control line. No important unfavourable correlated responses were realised in this experiment (Greeff et al., 1993c). The most important genetic association, i.e. between pattern and hair quality were small and insignificant, suggesting that it would be feasible to genetically improve both these traits together.

\subsubsection{Klerefontein Namaqua Afrikaner flock}

This flock of one of South Africa's oldest sheep breeds is maintained (conserved) under very arid conditions in the Karoo areas. Despite environmental constraints, levels of production of Namaqua Afrikaner sheep are acceptable with means of 4.3 to $4.5 \mathrm{~kg}$ for birth weight, 24.7 to $26.1 \mathrm{~kg}$ for weaning weight and 50.4 to $58.7 \mathrm{~kg}$ for 18-month-weight (Snyman et al., 1993). Reproduction traits averaged 1.56 lambs born per ewe lambed and 1.21 lambs weaned per ewe joined. The average age at first lambing was 16.5 months, while an average lambing interval of 279 days was recorded. The Namaqua Afrikaner thus seems capable of acceptable levels of production and reproduction, regardless of environmental constraints. Excessive accumulation of fat in the tail and poor fat distribution of the carcass of this breed make Namaqua Afrikaners unattractive for commercial production. However, the localised fat depots are seen to assist the breed with adaptation to harsh climates.

\subsubsection{Elsenburg Merino flock}

This flock was derived from ewes of the former S:P line of Heydenrych et al. (1984) being mated to CFW line and Control line rams at Tygerhoek. Marked, but slightly asymmetric genetic responses for reproduction resulted from the divergent selection experiment for the ability of ewes to rear multiples. Selection in the upward direction ( $\mathrm{H}$ line) resulted in direct responses of $1.5 \%$ per annum in number of lambs weaned per ewe joined, and 1.8 to $1.9 \%$ per annum in TWW (Cloete et al., 2004b, 2007b). Corresponding direct trends in the downward direction (L line) amounted from -0.8 to $-1.0 \%$ for number of lambs weaned and to -1.0 to $-1.2 \%$ for TWW. The divergent genetic trends for number of lambs weaned per ewe joined are provided in Fig. 3, as an illustration.

The realised direct responses were associated with an increased weaning weight in the $\mathrm{H}$ line and a reduced weaning weight in the L line (Cloete et al., 2003a). Accordingly, hogget weight in the $\mathrm{H}$ line increased, while hogget weight was reduced in the L line (Cloete et al., 2005a). $\mathrm{H}$ line progeny accordingly became plainer as far as skin fold development was concerned, while L line progeny became more developed. Divergent selection for reproduction did not have a marked effect on clean fleece weight or fibre diameter.

Lamb survival was improved in the $\mathrm{H}$ line compared to the L line (Cloete and Scholtz, 1998; Cloete et al., 2005b). This finding was particularly noticeable in multiple lambs. There was some evidence that the divergent selection for multiple lamb rearing ability led to behavioural adaptations favouring lamb survival in the $\mathrm{H}$ line (Cloete et al., 2003b, 2005b, 2006).

\subsubsection{Jansenville Angora or fine-mohair herd}

The establishment of a fine-mohair herd was enabled by sourcing animals from commercial and stud herds (Snyman, 2002). The objective was to breed goats with fine mohair and increased growth rates, while still adhering to the breed standards for Angora goats. Fleeces produced by fine-hair goats were finer than that of control goats at all stages of their lives (Snyman, 2002). Body weight was not compromised at any stage compared to the Control line, but fleece weight was generally reduced in the fine-mohair line. Genetic trends in

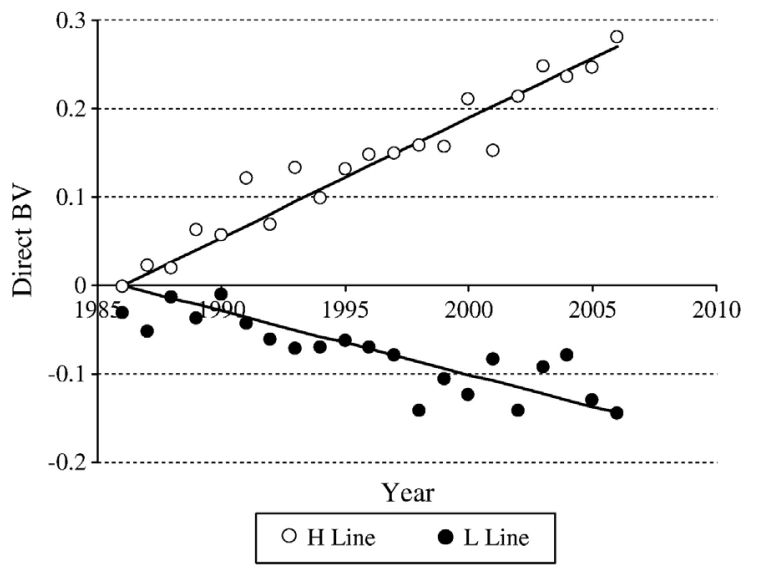

Fig. 3. Direct predicted breeding values (BVs) for number of lambs weaned per ewe joined in Merino lines divergently selected for multiple rearing ability ( $\mathrm{H}$ line), or against multiple rearing ability (L line).

The figure was derived from results presented by Cloete et al. (2007b). 
the fine-hair herd were favourable for fibre diameter, style, character and evenness, but mohair weight tended to decline (Snyman, 2002). A larger portion of the mohair produced by the fine-hair line could be classed in finer, higher value mohair classes, resulting in higher financial returns for producers.

\subsubsection{Klerefontein Dorper flock}

Perceptions in the South African Dorper industry were that animals with a hairy cover should be hardier than animals with a more woolly cover (Snyman and Olivier, 2002b). Two lines differing markedly in their cover were established and evaluated from 1993 to 2000. No differences in traits of economic importance were detected between the lines (Snyman and Olivier, 2002b). Carcass conformation suggested that hair-type animals were more compact in build, whereas wool-type animals appeared to be rangier. Wool type lambs had slightly heavier carcasses (19.6 vs. $19.2 \mathrm{~kg}$ ), and a slightly higher dressing percentage (49.9 vs. $49.0 \%$ ). In contrast, hair-type ewes were slightly heavier at joining than wool-type ewes ( $57.4 \mathrm{vs} .56 .4 \mathrm{~kg}$ ).

\subsubsection{Tygerhoek fine-wool Merino flock}

This flock was derived from the Cradock fine-wool stud,which will be discussed later. Initially rams and ewes were transferred from Cradock to Tygerhoek, while replacement rams were selected from within or obtained from the industry (including the Cradock stud) in subsequent years. Fine-wool sheep were initially $23 \%$ heavier than Control group contemporaries at 18 months of age (Cloete et al., 2001a). The clean fleece weight of the fine-wool line was $9 \%$ higher than in the Control line, while the 18-month fibre diameter of animals in the fine-wool line was $9 \%$ lower. Sustained genetic change was evident in the fine-wool line, and averaged breeding values for mean fibre diameter of progeny born from 1998 to 2005 declined by $0.193 \pm 0.029 \mu \mathrm{m}$ per annum ( $r=0.94$; S.W.P. Cloete, unpublished).

\subsection{Stud/demonstration flocks}

The resource flocks used for stud breeding, training and demonstration of genetic technology are listed in Table 2. The most important results from each of these flocks will be discussed briefly.

\subsubsection{Elsenburg Dormer flock}

The Dormer is a composite breed derived from a cross between the Dorset Horn and the then German Merino (now SA Mutton Merino) in the 1940s (Van Wyk, 1992). The breed was developed as a terminal sire breed for terminal crossbreeding on Merino-type dams (De Villiers and Cloete, 1984). Complete pedigrees from the inception of the stud were used to study environmental effects upon production (Van Wyk et al., 1993a), genetic parameters for early growth (Van Wyk et al., 1993b,e, 2003), genetic parameters for twinning and lamb survival (Konstantinov et al., 1994), genetic trends for early growth traits (Van Wyk et al., 1993d) and inbreeding (Van Wyk et al., 1993c, 2009). The genetic change in weaning weight in the flock was modest, at $0.071 \pm 0.002 \mathrm{~kg}$ per annum for 1943 to 1990 (Van Wyk et al., 1993d). The accumulated gain in weaning weight for the entire period amounted to slightly over $3 \mathrm{~kg}$.

The data set used by van Wyk et al. (1993c, 2009) was unique in the sense that data were available for the entire

Table 2

Details of South African resource flocks used for stud breeding and/or demonstration.

\begin{tabular}{|c|c|c|c|c|c|}
\hline Flock/stud & Breed & $\begin{array}{l}\text { Location } \\
\text { (province) }\end{array}$ & Time span & Selection objectives & Key references \\
\hline $\begin{array}{l}\text { Elsenburg Dormer } \\
\text { stud }\end{array}$ & Dormer & $\begin{array}{l}\text { Stellenbosch } \\
\text { (Western Cape) }\end{array}$ & 1941-present & $\begin{array}{l}\text { Improved growth and } \\
\text { conformation }\end{array}$ & $\begin{array}{l}\text { Fair (2002) } \\
\text { Van Wyk et al. } \\
(2003)\end{array}$ \\
\hline $\begin{array}{l}\text { Elsenburg SA Mutton } \\
\text { Merino stud }\end{array}$ & $\begin{array}{l}\text { SA Mutton } \\
\text { Merino }\end{array}$ & $\begin{array}{l}\text { Stellenbosch } \\
\text { (Western Cape) }\end{array}$ & 1955-present & $\begin{array}{l}\text { Improved growth, conformation and } \\
\text { twinning }\end{array}$ & $\begin{array}{l}\text { Zemuy (2002) } \\
\text { Cloete et al. } \\
(2004 c)\end{array}$ \\
\hline $\begin{array}{l}\text { Grootfontein Merino } \\
\text { stud }\end{array}$ & Merino & $\begin{array}{l}\text { Middelburg } \\
\text { (Eastern Cape) }\end{array}$ & 1968-present & $\begin{array}{l}\text { Conformation prior to } 1986 \\
\text { Increased live weight, reduced fibre diameter and } \\
\text { constant fleece weight (1986-1999) }\end{array}$ & $\begin{array}{l}\text { Olivier et al. (1994, } \\
\text { 1995) } \\
\text { Snyman et al. } \\
\text { (1998a) }\end{array}$ \\
\hline $\begin{array}{l}\text { Adelaide Improved } \\
\text { Boer goat herd }\end{array}$ & Boer goat & $\begin{array}{l}\text { Adelaide (Eastern } \\
\text { Cape) }\end{array}$ & 1978-1991 & $\begin{array}{l}\text { Not specified, bucks were supplied by the Breeders' } \\
\text { Association }\end{array}$ & $\begin{array}{l}\text { Van Niekerk et al. } \\
\text { (1996) }\end{array}$ \\
\hline $\begin{array}{l}\text { Halesowen Fine-wool } \\
\text { stud }\end{array}$ & Merino & $\begin{array}{l}\text { Cradock (Eastern } \\
\text { Cape) }\end{array}$ & 1988-present & $\begin{array}{l}\text { Increased live weight, fleece weigh 1988-1996 } \\
\text { More emphasis on fibre diameter since } 1996\end{array}$ & $\begin{array}{l}\text { Olivier et al. (1999, } \\
\text { 2006) }\end{array}$ \\
\hline $\begin{array}{l}\text { Klerefontein Afrino } \\
\text { flock }\end{array}$ & Afrino & $\begin{array}{l}\text { Carnarvon } \\
\text { (Northern Cape) }\end{array}$ & 1980-present & Reproduction & $\begin{array}{l}\text { Snyman et al. } \\
(1995,1998 b, c)\end{array}$ \\
\hline Glen Dorper flock & Dorper & Glen (Free State) & 1982-present & Breed traits to 1990 , afterwards performance & Neser et al. (2001) \\
\hline $\begin{array}{l}\text { Dohne Dohne Merino } \\
\text { flock }\end{array}$ & $\begin{array}{l}\text { Dohne } \\
\text { Merino }\end{array}$ & $\begin{array}{l}\text { Stutterheim } \\
\text { (Eastern Cape) }\end{array}$ & 1955-present & Breed type and conformation & $\begin{array}{l}\text { Fourie and } \\
\text { Heydenrych (1982) } \\
\text { De Klerk (1990) }\end{array}$ \\
\hline $\begin{array}{l}\text { Kromme Rhee } \\
\text { nucleus flock }\end{array}$ & $\begin{array}{l}\text { Dohne } \\
\text { Merino }\end{array}$ & $\begin{array}{l}\text { Stellenbosch } \\
\text { (Western Cape) }\end{array}$ & 1980-1998 & Dohne Merino selection objectives & $\begin{array}{l}\text { Cloete et al. } \\
\text { (1998b) }\end{array}$ \\
\hline $\begin{array}{l}\text { University of } \\
\text { Stellenbosch } \\
\text { studs }\end{array}$ & $\begin{array}{l}\text { Merino } \\
\text { Dohne } \\
\text { Merino } \\
\text { SA Mutton } \\
\text { Merino }\end{array}$ & $\begin{array}{l}\text { Stellenbosch } \\
\text { (Western Cape) }\end{array}$ & $\begin{array}{l}\text { Merino: } 1980- \\
1996 \\
\text { Other breeds: } \\
\text { 1980-present }\end{array}$ & Breed traits and breed objectives & $\begin{array}{l}\text { Cloete et al. (1999) } \\
\text { Cloete et al. } \\
\text { (2001b) }\end{array}$ \\
\hline
\end{tabular}


existence of the flock, since the initial crosses made to form the breed. It was thus ideal for the study of inbreeding. Although substantial levels of inbreeding were recorded in the flock (Van Wyk et al., 1993c, 2009), detrimental effects of inbreeding were limited to relatively small effects on birth and weaning weight (Van Wyk et al., 2009). In response to the need for genetic ties with other flocks, rams that were obtained from industry are used in combination with rams selected from within the flock at present.

\subsubsection{Elsenburg SA Mutton Merino flock}

The South African (SA) Mutton Merino breed is derived from the German Merino. The latter breed was imported to South Africa during 1932, on the advice of Mr. G.J. Schuurman, the then chief training officer of the Union of South Africa (Vosloo, 1967). The animals adapted well to local conditions, and further imports were done in 1936, 1937, 1949 and 1954. From a flock maintained at the Elsenburg Agricultural Centre, the breed spread throughout South Africa and is presently considered as one of the most important dual-purpose breeds. The breed was also used in the development of a number of composites, including the Dohne Merino (Kotzé, 1951), the Dormer (Van Wyk, 1992) and the Afrino (Snyman et al., 1995). From an initial distribution of predominantly the Western Cape of South Africa, the breed spread throughout South Africa. At present, SA Mutton Merinos are also exported as seedstock to a number of countries abroad.

The original SA Mutton Merino flock is still being maintained at Elsenburg. Data from the stud were used for the estimation of genetic parameters and trends in the study of Zemuy (2002). Traits considered included early growth traits, as well as yearling live weight and fleece traits. Despite relatively low additive variance ratios $\left(h^{2}=0.04\right.$ and $m^{2}=0.05$ ) for weaning weight, Zemuy (2002) reported that the direct and maternal genetic trends from 1955 to 1999 amounted to respectively $0.020 \pm 0.001$ and $0.019 \pm 0.001 \mathrm{~kg}$ per annum $(r \geq 0.80)$. Relative to the overall mean for weaning weight, these trends amounted to $\sim 0.07 \%$ per annum in both cases. Genetic parameters for yearling live weight and fleece traits in the flock were consistent with values reported for Merinos in the study of Cloete et al. (2004c). Direct genetic trends derived for yearling traits by Zemuy (2002) amounted to $0.083 \pm 0.010 \mathrm{~kg}$ for live weight $(r=0.83), 0.005 \pm 0.001 \mathrm{~kg}$ for clean fleece weight $(r=0.54)$ and to $0.019 \pm 0.007$ for mean fibre diameter $(r=0.32)$. Expressed as deviations of the overall phenotypic mean for these traits, these trends amounted to respectively $0.16,0.23$ and $0.08 \%$ per annum. Although the achieved responses were far below theoretical limits, it is evident that yearling live weight and fleece weight were emphasised in the selection of replacements.

\subsubsection{Grootfontein Merino stud}

As a well-known traditional Merino stud, research conducted on this resource flock contributed markedly to industry awareness and perceptions pertaining to what can be achieved by scientific selection (Olivier, 1989). Data from the flock were instrumental in genetic parameter estimation for live weight and wool traits (Olivier et al., 1994), as well as for reproduction (expressed as total weight of lamb weaned - Olivier et al., 1998b) and two-tooth wool and live weight traits (Snyman et al., 1998a).
Genetic trends in the stud were also studied in some detail (Olivier et al., 1995; Cloete et al., 2007b). Selection for overall excellence, as perceived by the classers working on the stud during 1968-1985, resulted in desirable improvements of $0.34 \%$ in hogget live weight and $0.48 \%$ in clean fleece weight relative to the overall phenotypic means. This selection regime also resulted in the wool becoming broader by $0.19 \%$ p.a. in this flock, which was not desirable. Olivier et al. (1995) related this trend to industry perceptions that stronger wool would also result in an increased clean fleece yield. Genetic trends corresponded with the selection objective strived for during the period from 1986 to 1999. Live weight increased by $0.86 \%$ per annum and clean fleece weight showed a slight increase of $0.24 \%$ per annum, while fibre diameter decreased at $0.33 \%$ per annum. The genetic trends for live weight and fibre diameter (as derived from Cloete et al., 2007b) are provided in Fig. 4 as an illustration. According to Fig. 4, the direction of change for live weight and fibre diameter corresponded with the report by Olivier et al. (1995) for the period from 1986 to 1991 . However, genetic changes were somewhat slower in the study by Cloete et al. (2007b). In contrast to the latter study, no response in CFW was reported by Olivier et al. (1995).

After 1999, the stud was subdivided in two lines, selected on indexes with slightly different aspects of overall production being emphasised (Olivier, 2007). A reduced fibre diameter was emphasised in one line, whereas more weight were placed on live weight and clean fleece weight in the other line. Although genetic trends in the respective component traits were somewhat different, line differences in the relative economic value of the two groups were barely perceptible. This exercise illustrates that economic aims can be realised in more than one way.

\subsubsection{Adelaide Improved Boer goat herd}

Data from the herd were used to derive heritability estimates for birth weight, weaning weight, ADG and Kleiber ratio (Van Niekerk et al., 1996; Schoeman et al., 1997). All traits were found to be heritable, and would respond to genetic selection. Genetic correlations were favourable

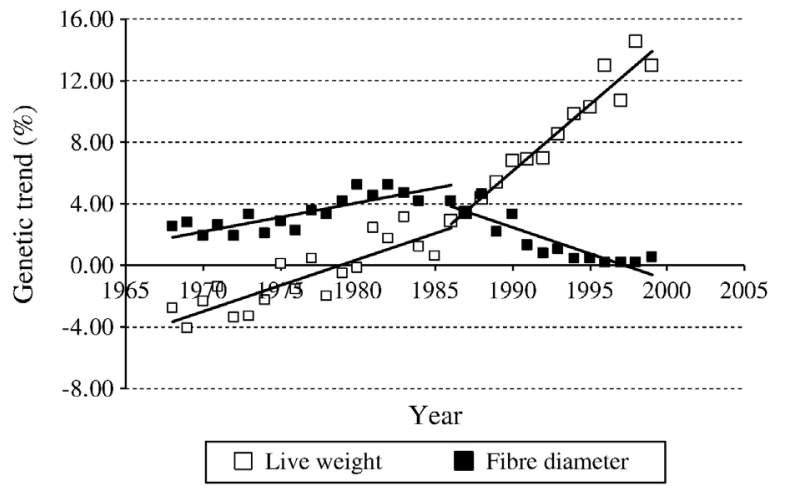

Fig. 4. Direct predicted breeding values (BVs) for live weight and fibre diameter in the Grootfontein Merino stud for the period 1968 to 1999. Animals were selected for overall excellence prior to 1986, while an increased live weight and a reduced fibre diameter were emphasised in subsequent years.

The figure was derived from results presented by Cloete et al. (2007b). 
among weight traits and for weight traits with ADG (Van Niekerk et al., 1996). The magnitude of these correlations declined as the time interval between recordings increased. The partitioning of the animal variances in the study of Schoeman et al. (1997) suggested a substantially lower direct heritability of 0.18 , a maternal heritability of 0.05 , with a negative direct-maternal correlation of -0.15 for weaning weight. It was concluded that the relatively low estimates of direct and maternal genetic variation, as well as the unfavourable direct-maternal correlation, would result in slow progress in kid weaning weight.

\subsubsection{Halesowen fine-wool Merino stud}

The stud was established during the late 1980s when Merino ewes of relatively fine-wool flocks were screened into a central flock. The ewes were purchased from their original owners and mated to 4 Australian fine-wool rams for 2 years. Olivier et al. (2006) reported genetic parameters for production traits in the flock. The stud was initially compared with progeny from overstrong ewes obtained from the Grootfontein Merino stud, that were mated to the same rams used in the fine-wool flock. Olivier et al. (1999) reported the phenotypic responses to the selection taking place in the first four generations. Fine-wool progeny outperformed fine $\mathrm{x}$ strong progeny for the first two generations when wool quality traits were considered, whereas crossbred progeny fared better for the other production traits. Line differences were not significant for most traits from the third generation onwards.

After being established the stud was initially selected for live weight and CFW during the 1988-1995 period. Mean fibre diameter did not receive a great deal of attention during this period. This strategy resulted in live weight increasing by $1.0 \%$ and CFW increasing by $1.2 \%$ of the overall phenotypic mean per annum (Cloete et al., 2007b). No significant selection pressure was directed at fibre diameter during this period, as reflected by a non-significant genetic trend. During the post-1995 era, the applied selection pressure to reduce fibre diameter resulted in a genetic trend amounting to $-0.67 \%$ per annum. The response in live weight was slower during this period at $0.35 \%$ per annum, while clean fleece weight remained stable. Genetic trends derived by Cloete et al. (2007b) are provided as illustration in Fig. 5.

Halesowen fine-wool rams were used in an upgrading experiment along with rams from the Grootfontein Merino stud. The progeny of this upgrading process were assessed during the period from 1989 to 1999 (Olivier and Roux, 2007). Progeny from the Grootfontein stud rams were heavier at birth (4.62 vs. $4.28 \mathrm{~kg}$ ) and at 15 months of age (38.7 vs. $37.9 \mathrm{~kg}$ ). However, mature ewes did not differ for body weight. CFW was higher for progeny of the Grootfontein stud rams ( 3.1 vs. $2.8 \mathrm{~kg}$ at 15 months and $3.5 \mathrm{vs} .3 .2 \mathrm{~kg}$ in adult ewes), while fibre diameter was broader (19.6 vs. $18.0 \mu \mathrm{m}$ at 15 months and 21.6 vs. $19.7 \mu \mathrm{m}$ in adult ewes). None of the components of reproduction rate was different between the lines and total lifetime weight of lamb weaned per ewe averaged $91.7 \mathrm{~kg}$ for the progeny of Grootfontein rams and $92.6 \mathrm{~kg}$ for the progeny of Halesowen fine-wool rams. It was demonstrated that the production of fine wool on natural Karoo pastures was feasible, which was contrary to the popular belief of the 1980s and 1990s.

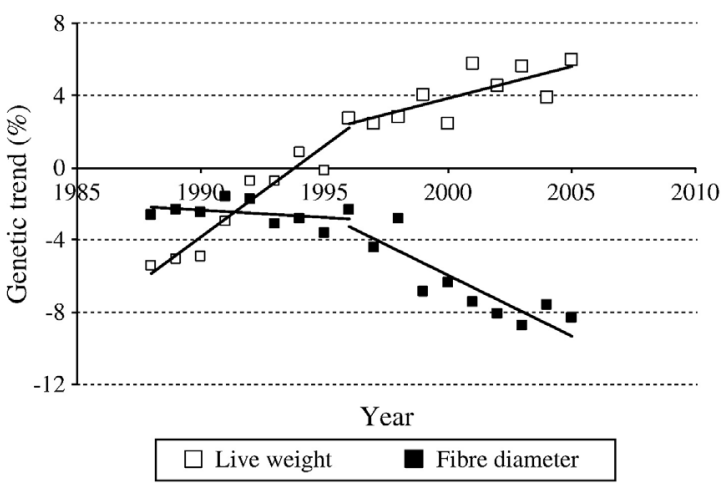

Fig. 5. Direct predicted breeding values (BVs) for live weight and fibre diameter in the Halesowen fine-wool Merino stud for the period 1988 to 2005. Animals were selected for live weight prior to 1996 , while fibre diameter received less attention. In subsequent years, less emphasis was placed on live weight, while it was strived to reduce fibre diameter at a faster rate.

The figure was derived from results presented by Cloete et al. (2007b).

\subsubsection{Klerefontein Afrino flock}

Intensive crossbreeding experiments were conducted at Klerefontein at the end of the 1970s, with the intention of the development of a suitable white-wool composite breed for the crossing of Merino ewes in the terminal crossbreeding situation (Olivier et al., 1984). The Afrino breed was established from these experiments and was composed of $1 / 4$ Merino, $1 / 4$ Ronderib Afrikaner and $1 / 2$ SA Mutton Merino. In subsequent years, the flock was selected for traits of economic importance and used for the estimation of genetic parameters for wool and live weight traits (Snyman et al., 1995), reproduction traits (Snyman et al., 1996a, 1997, 1998b,c), and type traits (Snyman and Olivier, 2002a). All traits of economic importance were shown to exhibit significant genetic variation, while unfavourable genetic correlations were limited to an unfavourable genetic correlation of -0.52 between clean fleece weight and total weight of lamb weaned (Snyman et al., 1998c), and of creeping belly with reproduction ( -0.33 ) and live weight ( -0.26 to -0.35 ; Snyman and Olivier, 2002a).

\subsubsection{Glen Dorper flock}

Data from this flock were used to estimate genetic parameter for birth weight, 42-day weight and weaning weight (Neser et al., 2001). All traits were moderately heritable and genetic progress is thus feasible. No mentionable genetic progress was found for any trait during the period from 1982 to 1990 , when selection was primarily based on breed standards. Expressed relative to overall trait phenotypic means, subsequent direct genetic gains amounted to $0.5 \%$ per annum for birth weight, $1.1 \%$ per annum for 42-day weight and $1.0 \%$ per annum for weaning weight. The corresponding maternal genetic trends were generally smaller in magnitude and therefore less apparent.

\subsubsection{Dohne Research Institute Dohne Merino flock}

The Dohne Merino breed was developed in the 1940s on the Dohne Agricultural Research Institute, as a composite with the Merino and the then German Merino as parent breeds. The Dohne Merino was originally intended for semi-intensive farming in the Eastern Cape grassland regions (Kotzé, 1951). However, it has since proved itself as adaptable under widely 
divergent conditions. This has resulted in sustained growth for the breed and expansion to other areas in South Africa (Laas, 1982). The breed adapted very well to South African conditions and became the main dual-purpose breed together with the SA Mutton Merino. Dohne Merino seedstock is presently being exported to other parts of the world.

The original Dohne Merino flock was used for the estimation of genetic parameters during the early 1980s (Fourie and Heydenrych, 1982). The flock has since been used to derive genetic trends (De Klerk, 1990). Derived genetic change in the latter study amounted to $0.059 \mathrm{~kg}$ per annum in 18 -month live weight and $0.004 \mathrm{~kg}$ per annum in greasy fleece weight measured at the same age. No worthwhile genetic change was evident in fibre diameter. The achieved levels of genetic change were generally slow compared to what may be achieved in theory. Clearly, there were other traits that were considered in the selection process.

\subsubsection{Kromme Rhee Dohne Merino nucleus flock}

This flock was run as the nucleus flock of the Western Cape Dohne Merino Club. The flock was founded in 1979, with 131 ewes donated by 15 club members. At first sires were obtained from breeders, but from 1984 joining only rams bred in the nucleus flock were used for breeding. Members continued to provide female breeding material. Club members donated about $40 \%$ of the female breeding material in later years, while $\sim 60 \%$ of replacement ewes were selected from within the nucleus flock. The flock was used for the estimation of genetic parameters and trends for yearling live weight, yearling clean fleece weight and yearling fibre diameter (Cloete et al., 1998b). The derived heritability values were the first animal model estimates for Dohne Merino sheep in South Africa. The obtained genetic change in live weight amounted to $0.26 \%$ of the overall phenotypic mean per annum $(r=0.85)$. The corresponding change in CFW was $0.79 \%$ per annum $(r=0.96)$. Genetic change in fibre diameter was slower, namely only $-0.011 \mu \mathrm{m}$ per annum $(r=0.38)$. This change was in the right direction, although it only amounted to $0.05 \%$ of the overall phenotypic mean. The selection policy of those involved in the selection of replacements in the nucleus flock clearly emphasised fleece weight, while fibre diameter was controlled at acceptable levels. Unfortunately the nucleus flock had to be disbanded in 1998, when a suitable locality for relocation could not be found.

\subsubsection{University of Stellenbosch studs}

The University of Stellenbosch maintained flocks of the Merino, Dohne Merino and SA Mutton Merino breeds at the Mariendahl Experimental farm. The studs were established from animals donated for research purposes. Selection procedures in all three studs were consistent with practices in the stud industry and the respective breed societies. Rams and, in rare cases, ewes were introduced from other leading studs of all breeds. Data from the studs were used to obtain an indication of breed differences for traits of economic importance (Cloete et al., 1999). Single births were more common in Merinos whereas pooled triplet and quadruplet litters were more common in the dual-purpose breeds, and particularly the SA Mutton Merino. Dohne Merino lambs were more likely to survive to weaning than SA Mutton Merino contemporaries, purebred Merino progeny being intermediate. Average lamb production ( $\mathrm{kg}$ of lamb weaned per lambed ewe per year) over three lambings was higher in SA Mutton Merinos (44.7 kg of lamb per season) than in Dohne Merinos (41.8 kg of lamb per season), while Dohne Merino ewes outperformed Merino ewes (31.3 kg of lamb per season) in this regard. Yearling SA Mutton Merinos were heavier than Dohne Merinos, which were heavier than Merinos. Merinos produced more clean wool than Dohne Merinos, which produced more clean wool than SA Mutton Merinos. The CFW of Dohne Merinos amounted to between 66.5 and $70.1 \%$ of the average performance of Merinos, while the wool weight of SA Mutton Merinos amounted to between 48.9 and $52.8 \%$ of that recorded in Merinos. The average fibre diameter of Merinos and Dohne Merinos was similar, but SA Mutton Merino wool was broader. Records from the studs were subsequently used for the estimation of heritability in the respective breeds (Cloete et al., 2001b). Worthwhile genetic variation was found in all three breeds. The Merino stud was phased out in 1996, but the other flocks are still maintained.

\subsection{Small stock genetic resources devoted to crossbreeding}

The main focus of this review is cumulative genetic gains stemming from additive gene action. However, it should be noted that some South African genetic resources were/are also used in crossbreeding situations. Brief mention will be made of these flocks/herds, but detailed information will be omitted. Substantial crossbreeding outlays involving multiple breeds were described by Erasmus et al. (1983) in the Southern Cape and by Greeff et al. (1990) in Gauteng. Greeff et al. (1989) evaluated the progeny of Finnish Landrace $\mathrm{x}$ Merino ewes for growth and survival and Greeff (1992) for slaughter traits. A study attempting to improve the hardiness of Angora goats by crossbreeding with the Boer goat was reported by Snyman (2004). Two hardy composite dam lines of small size were evaluated relative to Dorper ewes as dams in a terminal crossbreeding situation (Schoeman et al., 1995). Further crossbreeding studies involving Merino and Merinotype dam lines were conducted at the Langgewens experimental farm in the Swartland (Cloete and Durand, 2000; Cloete et al., 2004a). The improvement of carcass characteristics by the terminal crossing of Dorper ewes with sires from specialist sire breed types was investigated at the Nortier experimental farm on the Western Seaboard (Cloete et al., 2007a). The references cited can be consulted for further information on South African small stock crossbreeding experiments.

\subsection{General}

In addition to the large research output, which mainly focused on parameter estimation and the demonstration of genetic improvement in small stock, data generated over years were also used in numerous post graduate studies at different universities, and therefore human capital building. The resource flocks also play a significant role in formulating, refining and evaluating the breeding objectives that are currently applied in the national small stock flocks and herds. When the first wholebreed analyses were conducted, some resource flocks and herds contributed a substantial number of records to the initial 
assessments, while linkages with other leading studs and herds also markedly contributed to successful across-flock analyses.

\section{National flocks/herds}

According to the Abstract of Agricultural Statistics (2008) the Merino-types (Merino and Dohne Merino) represented $52.7 \%$ of total sheep numbers (21.92 million) in 2007 (Table 3). Non-wool sheep was 6.18 million of which the Dorper is the majority. Other woollen dual-purpose breeds totalled 4.16 million, which mainly consisted of the SA Mutton Merino. The total goat numbers amounted to 2.11 million, represented mainly by the Boer goats and Angora goats.

The national flocks also served as an important resource for the broadening of knowledge through research. Breed analyses were reported for the Merino (Olivier et al., 1998a; Olivier and Cloete, 2007), Dohne Merino (Van Wyk et al., 2008) and the Dorper (Olivier and Cloete, 2006).

\subsection{Improving reproductive rate}

With the current economic environment in South Africa, reproduction is by far the most important trait in Merino farming (Olivier, 1999). Improving some or all of its components can increase the net reproduction rate per ewe (defined as total weight of lamb weaned, accumulated over the lifetime of an ewe). Heritability estimates for net reproduction rate in South African Merino and Afrino flocks ranged from 0.13 to 0.26 (Snyman et al., 1997), while corresponding estimates were estimated at 0.13 to 0.22 in Merino flocks (Snyman et al., 1998a). Marked divergent changes in total weight of lamb weaned per ewe joined were also demonstrated (Cloete et al., 2004b), as pointed in the section on resource flocks (Section 2.1). These local studies were supported by overseas research indicating that litter weight weaned per ewe increased by $0.69 \mathrm{~kg}$ per year where both ram and ewe replacements were selected on the basis of total weight of lamb weaned (Ercanbrack and Knight, 1998). Selection for total weight of lamb weaned would also, in theory, keep reproductive rate within optimum bounds. Selection would be directed against a component of reproduction when undesirable change would result in a reduction of either lamb or ewe fitness, expressed as a reduction in litter weight weaned per ewe (Ercanbrack and Knight, 1998). The major objective of the NSIS is to increase the marketable weight of lamb produced per ewe, or in meat breeds, number

Table 3

National Small stock numbers and breed composition in commercial flocks in South Africa for 2007.

\begin{tabular}{lc}
\hline Category & Numbers (millions) ${ }^{*}$ \\
\hline Merino & 11.552 \\
Karakul & 0.035 \\
Other wool sheep & 4.161 \\
Non-wool sheep & 6.176 \\
Total sheep numbers & 21.924 \\
Goats & 2.106 \\
\hline
\end{tabular}

Source: Abstract of Agricultural Statistics (2008). of lambs weaned per ewe. It is feasible to record weaning weight (at approximately 100 days of age), since the number of lambs normally culled before this age is negligible. The recording of weaning weight forms the basis of the calculation of total weight of lamb weaned per breeding ewe in wool breeds. Age differences within a flock are accounted for by the regression of total weight of lamb weaned per ewe on her number of productive years. The number of productive years is calculated from the date of the last lambing (or the last possible lambing date for ewes that were barren in the reference year) and her own birth date. The individual weaning weights of lambs are adjusted for age and sex prior to the computation of weight of lamb weaned per breeding ewe. Total adjusted weight of lamb weaned per ewe is subsequently presented as a deviation from the mean of all the ewes within the same lambing season and present in the breeding flock for the same number of production years. This enables the comparison of ewes irrespective of age and of production level. These calculations result in a single measure of excellence in a breeding ewe, which is easily interpreted by both stud breeders and commercial farmers. Selection against poor producers is likely to result in current gains as well as gains in future generations. Such trends were already reported for the national Merino and Dorper flocks participating in the NSIS (Olivier and Cloete, 2006, 2007).

\subsection{Selection for growth}

Growth rate under natural production environments can be an indication of adaptability particularly in the adverse South African environment. Weaning weight is a possible selection criterion for early growth rate, however it has low direct heritability, maternal heritability and dam permanent environmental effect $(0.19,0.10$ and 0.07 , respectively in the South African Dorper breed; Olivier and Cloete, 2006). Live weights at older ages have higher direct and maternal heritabilities ( 0.24 and 0.14 for South African Dorpers, respectively) so should support sustained genetic progress in growth, however, they often have disadvantages as selection criteria because of preliminary culling and resultant small contemporary groups. It is therefore recommended to record an additional weight at approximately 270 or 365 days of age as a measurement of post-weaning growth.

\subsection{Selection for fibre traits}

The wool part of the performance scheme makes provision for body weight after shearing, fleece weight, fibre diameter, staple length, crimp frequency and clean yield. In regard to wool traits, NSIS makes provision for body weight after shearing, for fleece weight, fibre diameter, staple length, crimp frequency and clean yield. Parameter estimates for some of these traits in the Merino (Olivier and Cloete, 2007) and Dohne Merino (Van Wyk et al., 2008) breeds confirm that genetic progress should be attainable. Heritability estimates ranged from 0.17 (Dohne Merino) to 0.35 (Merino) for live weight, 0.19 (Dohne Merino) to 0.25 (Merino) for clean fleece weight and 0.45 (Dohne Merino) to 0.55 (Merino) for fibre diameter. Progress in both fibre diameter and other correlated traits should be feasible, as unfavourable genetic correlations are low (live weight with 
fibre diameter: 0.13 to 0.16 ; clean fleece weight with fibre diameter 0.16 to 0.20 ). These South African parameter estimates are consistent with those of Safari et al. (2005).

Research in Australia suggested genetic correlations ranging from -0.19 to -0.50 between coefficient of variation (CV) of fibre diameter and staple strength in seven Merino flocks (Greeff et al., 1995). A comparable estimate of -0.57 were found between these two traits in the Tygerhoek resource flock (Matebesi et al., 2009) suggesting that this result is probably robust for extension to the South African situation. Because of the additional cost of measuring staple strength, the deviation of $\mathrm{CV}$ of an animal from the mean $\mathrm{CV}$ is also calculated and can be used as indirect selection for stronger staple strength. As in the case of growth traits, reproduction performance of the dam is also supplied in the fibre reports.

\subsection{Recording system}

At present, most participants already record parentage, sex, birth type and birth date. Additional information to be recorded includes weaning weight and date as well as 270day or 365-day weight and date. Both reproduction and growth can be computed from these records. No carcass traits on live or slaughtered animals are presently being recorded, mainly due to cost associated with it. Information recorded on each breed is presented in Table 4.

Small stock breeding occasionally suffers from small contemporary groups or small single sire groups as well as long breeding seasons. To overcome this problem, contemporary groups in the NSIS are defined as all animals born on a farm within a mating season, limited to 60 days. Within this group, subgroups for different management strategies are allowed, provided that a specific minimum number of animals are included in each subgroup. Each contemporary group should contain progeny of at least three sires.

\subsection{Inputs} NSIS:

The following can be considered as input items into the

- Human capital (people involved; training and capacity building in participants)

The scheme is run by the ARC with 4 professional officers and 10 auxiliary staff.
- Infrastructure (fleece testing centre, computers, data capturing and editing, database management, on-farm software development)

A wool testing laboratory as well as a data capturing facility is used for data analysis and data capture. All data are verified according to prescribed norms and transferred to the Integrated Registration and Genetic Information System (INTERGIS) database. Data corrections and index calculations are done on the INTERGIS and made available to each participant. Data for routine breeding value analyses are downloaded from the INTERGIS and calculated values are updated on the system. On farm software are available for capturing and transferring (to and from) data and results.

Over the past 4 years the numbers of animals weighed increased substantially. In total 54870 live weights were submitted for 2003 born animals (all breeds). This number increased to 81392 weights submitted for 2006 born animals. The number of registered breeders participating in the scheme as a percentage of all registered breeders ranges from as low as $4.5 \%$ (Boer goats) to as high as 73\% (Dohne Merino) at present (Table 5). There is thus marked potential for further expansion of the scheme, mainly in breeds that are severely underrepresented (Boer goats, Dorper, Merino).

\subsection{Outputs}

\section{Output items of the NSIS are the following}

- Breeding objective development and guidance.

- Value adding by the conduction of breed analyses and the provision of decision support systems (National sire ratings).

- Availability of real-time breeding values. Breeding value calculations are done on a needs basis. These values are stored on the national database (INTERGIS) where it is available through the internet.

- Proven genetic and financial advantages (best scenario for wool and meat breeds - genetic trends of wool and meat client flocks; expressed in South African Rand - ZAR).

- Average genetic responses per breed in monetary values (presented in Table 6).

The genetic gains for the respective breeds varied from 0.098 (Dormer) to 0.818 (Merino) ZAR per small stock unit (SSU) per annum. The absolute genetic change in monetary

Table 4

Individual traits recorded and individual sire rating available for each breed in the NSIS.

\begin{tabular}{|c|c|c|c|c|c|c|c|}
\hline \multirow[t]{2}{*}{ Traits } & \multicolumn{7}{|l|}{ Breeds } \\
\hline & Boer goat & Dormer & Dorper & Ilde France & S.A. Mutton merino & Merino & Dohne merino \\
\hline Birth weight (direct and maternal) & $\mathrm{X}$ & $\mathrm{X}$ & $\mathrm{X}$ & $\mathrm{X}$ & $\mathrm{X}$ & & \\
\hline Pre weaning weight (direct and maternal) & & & & $\mathrm{X}$ & & & \\
\hline Weaning weight (direct and maternal) & $\mathrm{X}$ & $\mathrm{X}$ & $\mathrm{X}$ & $\mathrm{X}$ & $\mathrm{X}$ & $\mathrm{X}$ & \\
\hline Post weaning weight (direct) & $\mathrm{X}$ & $\mathrm{X}$ & $\mathrm{X}$ & & $\mathrm{X}$ & $\mathrm{X}$ & \\
\hline Reproduction (number or weight weaned) & $\mathrm{X}$ & $\mathrm{X}$ & $\mathrm{X}$ & $\mathrm{X}$ & $\mathrm{X}$ & $\mathrm{X}$ & \\
\hline Yearling weight & & & & & & $\mathrm{X}$ & $\mathrm{X}$ \\
\hline Clean fleece weight & & & & & & $\mathrm{X}$ & $\mathrm{X}$ \\
\hline Fibre diameter & & & & & & $\mathrm{X}$ & $\mathrm{X}$ \\
\hline Staple length & & & & & & $\mathrm{X}$ & \\
\hline Wool and conformation scores & & & & & & $\mathrm{X}$ & \\
\hline Relative economic value (ZAR per small stock unit per year) & $\mathrm{X}$ & $\mathrm{X}$ & $\mathrm{X}$ & $\mathrm{X}$ & $\mathrm{X}$ & $\mathrm{X}$ & $\mathrm{X}$ \\
\hline
\end{tabular}




\section{Table 5}

The number of registered breeders, average ewe numbers per breeder for 2008 at some of the major breed societies, as well as the number of breeders with animals born during 2006 and with weights recorded on the INTERGIS.

\begin{tabular}{|c|c|c|c|c|}
\hline Breed & $\begin{array}{l}\text { Number } \\
\text { of stud } \\
\text { breeders }\end{array}$ & $\begin{array}{l}\text { Average number } \\
\text { of ewes/does } \\
\text { per breeder }\end{array}$ & $\begin{array}{l}\text { Number of } \\
\text { participating } \\
\text { breeders }\end{array}$ & $\begin{array}{l}\text { Weaning weights } \\
\text { recorded per } \\
\text { annum }\end{array}$ \\
\hline $\begin{array}{c}\text { Angora } \\
\text { goat }\end{array}$ & 49 & 150 & 4 & 1253 \\
\hline $\begin{array}{l}\text { Boer } \\
\text { goat }\end{array}$ & 270 & 165 & 12 & 2238 \\
\hline $\begin{array}{l}\text { Dohne } \\
\text { Merino }\end{array}$ & 98 & 261 & $\begin{array}{l}34 \\
(72)^{a}\end{array}$ & $\begin{array}{l}14270 \\
(18432)^{a}\end{array}$ \\
\hline Dorper & 643 & 146 & 70 & 19995 \\
\hline Dormer & 95 & 143 & 34 & 5908 \\
\hline $\begin{array}{l}\text { Ile de } \\
\text { France }\end{array}$ & 60 & 76 & 20 & $1575^{b}$ \\
\hline Merino & 305 & 322 & $\begin{array}{l}39 \\
(39)^{a}\end{array}$ & $\begin{array}{l}24203 \\
(14406)^{a}\end{array}$ \\
\hline $\begin{array}{l}\text { SA Mutton } \\
\text { Merino }\end{array}$ & 180 & 145 & 108 & 14490 \\
\hline
\end{tabular}

a Breeders and number of wool samples analysed.

b Pre weaning weights recorded.

value (ZAR 1.347) was the highest in the Dohne Merino. This response cannot be compared to the other breeds due to the fact that a reproduction trait was not included in the selection index (since no reproduction data was available). In accordance with these results, Banks (2005) reported an average monetary gain of 0.14 AUD per SSU for Merino flocks participating in the Sheep Genetics Australia scheme. When compared to the best response for individual studs, it is evident that genetic change per breed was well below the maximum, as was also demonstrated by Olivier and Cloete (2007) for the Merino breed. The gain in leading Australian Merino flocks amounted to 0.56 AUD per SSU (Banks, 2005), representing a fourfold increase. These values are comparable to the South African figures presented in Table 6. It is clear that by applying correct breeding strategies, as demonstrated in some flocks and herds, there is huge potential for genetic improvement.

The impact of this change in the industry is quite substantial. For example, when the SAMM breed (with an estimated 4 million animals) is considered, an additional income of nearly R 700000 per annum accrues in the national flock if a third of the available animals (one generation) are improved at a rate of R0.584 per SSU per annum. If the same calculation is applied to the Merino breed, the additional income is equal to R 2.45 million per annum. When genetic gains accrue at the present rate, Banks (2005) indicated that

\section{Table 6}

Average genetic response in monitory value (born from 2000 to 2006) per breed as well as the best response per individual stud per breed.

\begin{tabular}{lll}
\hline Breed & Average response (ZAR) & Best individual stud (ZAR) \\
\hline Boer goat & $0.281 \pm 0.090$ & $1.341 \pm 0.351$ \\
Dormer & $0.098 \pm 0.061$ & $0.949 \pm 0.082$ \\
Dorper & $0.122 \pm 0.030$ & $2.610 \pm 0.325$ \\
Ile de France & $0.576 \pm 0.196$ & $1.035 \pm 0.696$ \\
SA Mutton Merino & $0.584 \pm 0.031$ & $1.060 \pm 0.329$ \\
Dohne Merino $^{\text {a }}$ & $1.347 \pm 0.114$ & $2.569 \pm 0.414$ \\
Merino & $0.818 \pm 0.089(0.65)$ & $2.359 \pm 0.809(2.6)$ \\
\hline
\end{tabular}

${ }^{\text {a }}$ Excluding reproduction traits. the Australian extensive livestock industries will contribute an additional 45 million AUD per annum to the economy.

In the investigation by Makoena (1999) on the efficiency of research and development of the different improvement schemes an internal rate of return of $54 \%$ was estimated for the mutton sheep performance scheme over a ten-year period. This figure therefore indicates that for every one Rand spent on research and development, the return over the period was R1.54. It was furthermore shown that consumers benefit more than producers from investment in research and development in sheep breeding in South Africa.

\section{Conclusions}

In a country with limited agricultural potential for intensive production, extensive small stock production has to play an important role. Although the small stock industry only contributes $8.2 \%$ of the total gross value of animal products (ZAR 35.28 billion) it is of cardinal local importance. Because large arid areas in South Africa are only suitable for extensive small stock production, and small stock is also well adapted to complement the more capital-intensive cropping industries, many rural communities depend on this industry for their very livelihood. Knowledge gathered from 19 resource flocks contributed substantially to formulate breeding plans under South African production conditions. These results are incorporated into the NSIS, focusing on the genetic improvement of traits of economic importance. Even at modest industry gains by participating flocks, it was demonstrated that genetic improvement of small stock could contribute substantially to monetary margins within the industry. It is therefore foreseen that the industry will continue to contribute to rural sustainability. Based on the present review it is clear that there is still a vast potential to further expand the contribution of small stock to the national economy if the genetic improvement of whole breeds could be elevated to those levels attained by the leading flocks and herds.

\section{References}

Abstract of Agricultural Statistics, 2008. Directorate: Agricultural Information Services, Private Bag X144, Pretoria, 0001. . 115 pp.

Banks, R.G., 2005. Challenges with investing in genetic improvement for the Australian extensive livestock industries. Aust. J. Exp. Agric. 45, 1033-1039.

Cloete, S.W.P., Durand, A., 2000. The crossing of commercial Merino ewes with South African (SA) Meat Merino rams for an increased lamb output. Aust. J. Exp. Agric. 40, 11-16.

Cloete, S.W.P. Scholtz, A. 1998. Lamb survival in relation to lambing and neonatal behaviour in medium wool Merino lines divergently selected for multiple rearing ability. Aust. J. Exp. Agric. 38, 801-811.

Cloete, S.W.P., Delport, G.J., Erasmus, G.J., Olivier, J.J., Heydenrych, H.J., Du Toit, E., 1992. Environmental and genetic trends in clean fleece mass, live mass and fibre diameter in selection and control flocks involving a selection experiment for increased clean fleece mass in South African Merino sheep. S. Afr. J. Anim. Sci. 22, 50-57.

Cloete, S.W.P., Olivier, J.J., Snyman, M.A., Du Toit, E., 1998a. Genetic parameters and trends in a selection experiment for increased clean fleece weight involving South African Merinos. Aust. J. Exp. Agric. 38, 427-432.

Cloete, S.W.P., Scholtz, A.J., Aucamp, B.B., 1998b. Environmental effects, heritability estimates and genetic trends in a Western Cape Dohne Merino nucleus flock. S. Afr. J. Anim. Sci. 28, 185-195.

Cloete, S.W.P., Coetzee, J., Schoeman, S.J., Morris, J., Ten Hoope, J.M., 1999. Production parameters for Merino, Dohne Merino and South African Mutton Merino sheep. Proc. Assoc. Advmnt Anim. Breed. Gen. 13, 181-184.

Cloete, S.W.P., Olivier, J.J., Du Toit, E., 2001a. Blowfly Strike of Merino Sheep in Relation to Selection Strategy, as well as to Objective and Subjective 
Wool Traits. Proc. Flystrike \& Lice IPM Control Strategy Conf., 22-25 June 2001, Launceston, Tasmania, pp. 395-401.

Cloete, S.W.P., Schoeman, S.J., Coetzee, J., Morris, J.de V., 2001b. Genetic variances for liveweight and fleece traits in Merino, Dohne Merino and South African Meat Merino sheep. Aust. J. Exp. Agric. 41, 145-153.

Cloete, S.W.P., Olivier, J.J., Van Wyk, J.B., Erasmus, G.J., Schoeman, S.J., 2003a. Genetic parameters and trends for birth weight, birth coat score and weaning weight in Merino lines divergently selected for ewe multiple rearing ability. S. Afr. J. Anim. Sci. 33, 248-256.

Cloete, S.W.P., Van Wyk, J.B., Scholtz, A.J., Gilmour, A.R., 2003b. Genetic and environmental parameters for lambing behaviour in Merino lines divergently selected for ewe maternal rearing ability. Proc. N. Z. Soc Anim. Prod. 63, 169-172.

Cloete, S.W.P., Cloete, J.J.E., Herselman, M.J., Hoffman, L.C., 2004a. Relative performance and efficiency of five Merino and Merino-type dam lines in a terminal crossbreeding system with Dormer or Suffolk sires. S. Afr. J. Anim. Sci. 34, 135-143.

Cloete, S.W.P., Gilmour, A.R., Olivier, J.J., Van Wyk, J.B., 2004b. Genetic and phenotypic trends and parameters in reproduction, greasy fleece weight and live weight in Merino lines divergently selected for multiple rearing ability. Aust. J. Exp. Agric. 44, 745-754.

Cloete, S.W.P., Van Wyk, J.B., Neser, F.W.C., 2004c. Estimates of genetic and environmental (co) variances for live weight and fleece traits in yearling South African Mutton Merino sheep. S. Afr. J. Anim. Sci. 34, 37-43.

Cloete, S.W.P., Olivier, J.J., Van Wyk, J.B., Schoeman, S.J., Erasmus, G.J., 2005a. Genetic parameters and trends for hogget traits in Merino lines divergently selected for multiple rearing ability. Proc. Assoc. Advmnt Anim. Breed. Gen. 16, 24-27.

Cloete, S.W.P., Scholtz, A.J., Cloete, J.J.E., Van Wyk, J.B., 2005b. The ability of Merino ewes and lambs to reunite after separation, as affected by divergent selection for ewe multiple rearing capacity. Aust. J. Exp. Agric. $45,1131-1137$.

Cloete, S.W.P., Van Wyk, J.B., Scholtz, A.J., Gilmour, A.R., 2006. Genetic Parameters and Trends for Lamb Behaviour. Proc. 7th World Cong. Gen. Appl. Livest. Prod., Bello Horizonte, Brazil. CD communication 17-07.

Cloete, J.J.E., Cloete, S.W.P., Olivier, J.J., Hoffman, L.C., 2007a. Terminal crossbreeding of Dorper ewes to Ile de France, Merino Landsheep and SA Mutton Merino sires: ewe production and lamb performance. Small Rumin. Res. 69, 28-35.

Cloete, S.W.P., Olivier, J.J., Olivier, W.J., 2007b. Genetic change in South African Merino resource flocks. Proc. Assoc. Advmnt Anim. Breed. Gen. $17,320-323$.

De Klerk, H.C., 1990. Genetic Trends in the Dohne Merino. M.Sc.Agric. Thesis, University of Stellenbosch.

De Villiers, T.T., Cloete, S.W.P., 1984. The Dormer Sheep Breed. In: Hofmeyr, J.H., Meyer,E.H.H. (Eds.), Proc. 2nd World Cong. Sheep Beef Cattle Breed., 16-19 April, Pretoria. South African Stud Book and Livestock Improvement Association, Bloemfontein, pp. 695-698.

Delport, G.J., 1989. A Mixed Model Approach for Selecting Merino ewes. Ph.D. Dissertation, University of the Free State, Bloemfontein, South Africa.

Erasmus, G.J., 1988. A Mixed Model Analysis of a Selection Experiment with Merino Sheep is an Arid Environment. Ph.D. Dissertation, University of the Free State, Bloemfontein, South Africa.

Erasmus, G.J. 1990. Genetic Stability of Two Merino Sheep Control Populations. Proc. 4th World Cong. Gen. Appl. Livest. Prod. 15, 81-83. Edinburgh, 23-27 July 1990.

Erasmus, G.J., Hofmeyr, J.H., 1984. The Development of Performance Recording Programmes for Woolled Sheep in South Africa. In: Hofmeyr, J.H., Meyer, E.H.H. (Eds.), Proc. 2nd World Cong. Sheep and Beef Cattle Breed., 16-19 April 1984, Pretoria. South African Stud Book and Livestock Improvement Association, Bloemfontein, pp. 252-256.

Erasmus, L.S., De Kock, J.A., Grobler, J.W., 1983. Slaglamproduksie in die SuidKaap. Els. J. 7, 13-32 In Afrikaans.

Erasmus, G.J.De., Lange, A.O., Delport, G.J., Olivier, J.J., 1990. Genetic and phenotypic parameter estimates of production traits of Merino sheep in an arid environment. S. Afr. J. Anim. Sci. 20, 31-34.

Ercanbrack, S.K., Knight, A.D., 1998. Responses to various selection protocols for lamb production in Rambouillet, Targhee, Columbia and Polypay sheep. J. Anim. Sci. 76, 1311-1325.

Fair, M.D., 2002. Genetic parameter estimation of production and reproduction traits of the Elsenburg Dormer stud. M.Sc. thesis. University of the Free State, South Africa.

Fourie, A.J., Heydenrych, H.J., 1982. Phenotypic and genetic aspects of production in the Dohne Merino. II. Estimation of heritabilities of production traits. S. Afr. J. Anim. Sci. 12, 61-64.

Greeff, J.C., 1992. Evaluation of the Finnish Landrace x Merino and Merino as dam lines in crosses with five sire lines: slaughter and carcass traits of ram lambs. S. Afr. J. Anim. Sci. 22, 21-30.

Greeff, J.C., Wyma, G.A., Van Deventer, J.F.P.J., Greyling, J.P.C., Brink, W., 1989. Evaluation of Finnish Landrace x Merino and Merino as ewe lines in crosses with five ram lines. Survival and growth (In Afrikaans). S. Afr. J. Anim. Sci. 19, 93-96.

Greeff, J.C., Roux, C.Z., Wyma, G.A., 1990. Lifetime meat production from six different F1 crossbred ewes. S. Afr. J. Anim. Sci. 20, 71-77.

Greeff, J.C., Faure, A.S., Minnaar, G.J., Schoeman, S.J., 1993a. Genetic and phenotypic parameters of pelt traits in Karakul sheep. S. Afr. J. Anim. Sci. 33, 156-161.

Greeff, J.C., Faure, A.S., Minnaar, G.J., Schoeman, S.J., 1993b. Genetic trends of selection for pelt traits in Karakul sheep. 1. Direct responses. S. Afr. J. Anim. Sci. 33, 162-169.

Greeff, J.C., Faure, A.S., Minnaar, G.J., Schoeman, S.J., 1993c. Genetic trends of selection for pelt traits in Karakul sheep. II. Correlated responses. S. Afr. J. Anim. Sci. 33, 170-175.

Greeff, J.C., Lewer, R.P., Ponzoni, R.W., Purvis, I.W., 1995. Staple strength: progress towards elucidating its place in Merino breeding. Proc. Assoc. Advmnt Anim. Breed. Gen. 11, 595-601.

Heydenrych, H.J., Du Plessis, J.J., Cloete, S.W.P., 1984. Increasing the Wool Production of Merino Sheep in the South Western Districts of South Africa by Direct and Indirect Selection. In: Hofmeyr, J.H., Meyer, E.H.H. (Eds.), Proc. 2nd World Cong. Sheep Beef Cattle Breed., 16-19 April, Pretoria. South African Stud Book and Livestock Improvement Association, Bloemfontein, pp. 399-412.

Konstantinov, K.V., Erasmus, G.J., Van Wyk, J.B., 1994. Evaluation of Dormer sires for litter size and lamb mortality using a threshold model. S. Afr. J. Anim. Sci. 24, 119-121.

Kotzé, J.J.J., 1951. The development of a mutton-woolled sheep for the Sourgrassveld area. Farm. S. Afr. Reprint no. 26, 110-113.

Laas, T.M., 1982. Faktore wat die produksievermoë van wolskape beïnvloed. D.Sc.-Agric.-dissertation, University of Pretoria (in Afrikaans).

Makoena, M.R., 1999. Impact Assessment of Livestock Production Research in South Africa. M.Inst.Agrar. (Agricultural Economics). University of Pretoria, Pretoria, South Africa.

Matebesi, P.A., Cloete, S.W.P., Van Wyk, J.B., 2009. Genetic parameter estimation of 16-month live weight and objectively measured wool trait in the Tygerhoek merino flock. S. Afr. J. Anim. Sci. 39, 73-82.

Neser, F.W.C., Konstantinov, K.V., Erasmus, G.J., 1995. Estimated genetic trends for weaning weight in three Dorper lines with different selection criteria. S. Afr. J. Anim. Sci. 25, 65-69.

Neser, F.W.C., Erasmus, G.J., Van Wyk, J.B., 2001. Genetic parameters for preweaning weight traits in Dorper sheep. Small Rumin. Res. 40, 197-202.

Olivier, J.J., 1981. Die invloed van objektiewe en subjektiewe seleksiemetodes en omgewingsfaktore op produksie- en reproduksie eienskappe van Merinoskape op die Carnarvon-proefplaas (in Afrikaans). M.Sc. Thesis, University of Stellenbosch, Stellenbosch, South Africa.

Olivier, J.J., 1989. Genetic and Environmental Trends in the Grootfontein Merino Stud. Ph.D. Dissertation, University of the Free State, Bloemfontein, South Africa.

Olivier, J.J., 1999. The South African Merino Performance Testing Scheme. Rising to the Challenge - Breeding for the 21st Century Customer. Beef Industry and CRC for Premium Quality Wool Industry Symposia. Supplement to the Proc. Assoc. Advmnt Anim. Breed. Gen, pp. 119-124.

Olivier, W.J., 2007. Investigation into the Selection Criteria of Merino Sheep. Annual Report of the Grootfontein Agricultural Development Institute, Department: Agriculture, Pretoria. Obtainable from: Grootfontein Agricultural Development Institute, Private Bag X529, Middelburg 5900, EC, South Africa, pp. 9-10.

Olivier, J.J., Cloete, S.W.P., 2006. Genetic Analysis of the South African Dorper Sheep. Proc. 7th World Cong. Gen. Appl. Livest. Prod., Bello Horizonte, Brazil: Communication, pp. 04-10.

Olivier, J.J., Cloete, S.W.P., 2007. Genetic change in some South African Merino studs participating in the Merino plan. Proc. Assoc. Advmnt Anim. Breed. Gen. 17, 324-327.

Olivier, W.J., Roux, J.A., 2007. Productions and reproduction norms for fine woolled Merino sheep on natural pastures in the Karoo. S. Afr. J. Anim. Sci 37, 31-34.

Olivier, J.J., Marais, P.G., Cloete, J.A.N., 1984. Evaluation of different breed crosses in the development of a white-wooled mutton sheep breed: the Afrino. S. Afr. J. Anim. Sci 14, 105-109.

Olivier, J.J., Erasmus, G.J., Van Wyk, J.B., Konstantinov, K.V., 1994. Direct and maternal variance component estimates for clean fleece weight, body weight and fibre diameter in the Grootfontein Merino stud. S. Afr. J. Anim. Sci. 24, 122-124.

Olivier, J.J., Erasmus, G.J., Van Wyk, J.B., Konstantinov, K.V., 1995. Response to selection for the BLUP of breeding values in the Grootfontein Merino stud. S. Afr. J. Anim. Sci. 25, 13-15.

Olivier, J.J., Yurgens, Y., Mostert, B.E., Erasmus, G.J., 1998a. Across-stud evaluation of Merinos in South Africa. Proc. 6th World Cong. Gen. Appl. Livest. Prod. 24, 11-14.

Olivier, W.J., Snyman, M.A., van Wyk, J.B., Erasmus, G.J., 1998b. Genetic parameters for fitness traits in Merino sheep. Livest. Prod. Sci. 56, 71-77. 
Olivier, J.J., Bezuidenhout, A.G., Greyling, A.C., Cloete, S.W.P., 1999. Evaluation of genetic fine and fine $\mathrm{X}$ strong wool Merinos on irrigated pastures. Proc. Assoc. Advmnt Anim. Breed. Gen. 13, 62-65.

Olivier, W.J., Olivier, J.J., Cloete, S.W.P., Van Wyk, J.B., 2006. Genetic Analysis of the Cradock fine Wool Merino Stud. Proc. 7th World Cong. Gen. Appl. Livest. Prod., Bello Horizonte, Brazil: Communication, pp. 05-09.

Safari, E., Fogarty, N.M., Gilmour, A.R., 2005. A review of genetic parameters for wool, growth, meat and reproduction traits in sheep. Livest. Prod. Sci. 92, 271-289.

Schoeman, S.J., De Wet, R., Botha, M.A., Van der Merwe, C.A., 1995. Comparative assessment of biological efficiency of crossbred lambs from two composite lines and Dorper sheep. Small Rumin. Res. 16, 61-67.

Schoeman, S.J., Els, J.F., Van Niekerk, M.M., 1997. Variance components of early growth traits in the Boer goat. Small Rumin. Res. 26, 15-20.

Snyman, M.A., 2002. Evaluation of a genetically fine mohair producing herd. Small Rumin. Res. 43, 105-113.

Snyman, M.A., 2004. Mohair production and reproduction of Angora and Angora $\mathrm{x}$ Boer goat genotypes in a sub-optimum environment. Small Rumin. Res. 53, 105-113.

Snyman, M.A., Olivier, W.J., 2002a. Correlations of subjectively assessed fleece and conformation traits with production and reproduction in Afrino sheep. S. Afr. J. Anim. Sci. 32, 88-96.

Snyman, M.A., Olivier, W.J., 2002b. Productive performance of hair and wool type Dorper sheep under extensive conditions. Small Rumin. Res. 45, 17-23.

Snyman, M.A., Olivier, J.J., Cloete, J.A.N., 1993. Productive and reproductive performance of Namaqua Afrikaner sheep. Karoo Agric. 5 (2), 21-24.

Snyman, M.A., Erasmus, G.J., Van Wyk, J.B., 1995. Direct and maternal (co) variance components and heritability estimates for body weight at different ages and fleece traits in Afrino sheep. Livest. Prod. Sci. 44, 229-235.

Snyman, M.A., Erasmus, G.J., Van Wyk, J.B., Olivier, J.J., 1996a. Genetic parameter estimates for total weight of lamb weaned in Afrino and Merino sheep. Livest. Prod. Sci. 48, 111-116.

Snyman, M.A., Olivier, J.J., Olivier, W.J., 1996b. Variance components and genetic parameters for body weight and fleece traits of Merino sheep in an arid environment. S. Afr. J. Anim. Sci. 26, 11-14.

Snyman, M.A., Olivier, J.J., Erasmus, G.J., Van Wyk, J.B., 1997. Genetic parameter estimates for total weight of lamb weaned in Afrino and Merino sheep. Livest. Prod. Sci. 48, 111-116.

Snyman, M.A., Cloete, S.W.P., Olivier, J.J., 1998a. Genetic and phenotypic correlations of total weight of lamb weaned with body weight, clean fleece weight and mean fibre diameter in three South African Merino flocks. Livest. Prod. Sci. 55, 157-163.
Snyman, M.A., Erasmus, G.J., Van Wyk, J.B., 1998b. The possible improvement of reproduction and survival rate in Afrino sheep using a threshold model. S. Afr. J. Anim. Sci. 28, 120-124.

Snyman, M.A., Erasmus, G.J., Van Wyk, J.B., Olivier, J.J., 1998c. Genetic and phenotypic correlations among production and reproduction traits in Afrino sheep. S. Afr. J. Anim. Sci. 28, 74-81.

Van Niekerk, M.M., Schoeman, S.J., Botha, M.E., Casey, N., 1996. Heritability estimates for pre-weaning growth traits in the Adelaide Boer goat flock. S. Afr. J. Anim. Sci. 26, 6-10.

Van Wyk, J.B., 1992. A Genetic Evaluation of the Elsenburg Dormer Stud. Ph.D. Thesis, University of the Free State, Bloemfontein, South Africa.

Van Wyk, J.B., Erasmus, G.J., Konstantinov, K.V., 1993a. Non-genetic factors influencing early growth traits in the Elsenburg Dormer sheep stud. S. Afr. J. Anim. Sci. 23, 67-71.

Van Wyk, J.B., Erasmus, G.J., Konstantinov, K.V., 1993b. Variance component and heritability estimates of early growth traits in the Elsenburg Dormer sheep stud. S. Afr. J. Anim. Sci. 23, 72-76.

Van Wyk, J.B., Erasmus, G.J., Konstantinov, K.V., 1993c. Inbreeding in the Elsenburg Dormer sheep stud. S. Afr. J. Anim. Sci. 23, 77-80.

Van Wyk, J.B., Erasmus, G.J., Konstantinov, K.V., 1993d. Genetic and environmental trends of early growth traits in the Elsenburg Dormer sheep stud. S. Afr. J. Anim. Sci. 23, 85-87.

Van Wyk, J.B., Erasmus, G.J., Konstantinov, K.V., Van der Westhuizen, J., 1993e. Relationships between early growth traits in the Elsenburg Dormer sheep stud. S. Afr. J. Anim. Sci. 23, 81-84.

Van Wyk, J.B., Fair, M.D., Cloete, S.W.P., 2003. Revised models and genetic parameters for production and reproduction traits in the Elsenburg Dormer stud. S. Afr. J. Anim. Sci. 33, 213-222.

Van Wyk, J.B., Swanepoel, J.W., Cloete, S.W.P., Olivier, J.J., Delport, G.J., 2008. Across flock genetic parameter estimation for yearling body weight and fleece traits in the South African Dohne Merino population. S. Afr. J. Anim. Sci. 38, 31-37.

Van Wyk, J.B., Fair, M.D., Cloete, S.W.P., 2009. Case study: the effect of inbreeding on the production and reproduction traits in the Elsenburg Dormer sheep stud. Livest. Sci. 120, 218-224.

Vosloo, L.P., 1967. Faktore wat die produksie en reproduksie van die Elsenburg Duitse Merinokudde beïnvloed (in Afrikaans). D.Sc. dissertation, University of Stellenbosch, Stellenbosch, South Africa.

Zemuy, E.G., 2002. Genetic Improvement of Production and Wool Traits in the Elsenburg Mutton Merino Flock. M.Sc. (Agric.) Thesis, University of the Free State, Bloemfontein, South Africa. 